\title{
Determinant Factors affecting Maternal Death in Boyolali District
}

\author{
${ }^{1}$ Supriyadi H Respati, ${ }^{2}$ Andrew C Taufiq, ${ }^{3}$ Sri Sulistyowati
}

\section{ABSTRACT}

Introduction: To identify determinants of maternal death, which consisted of close determinants (obstetric complications), intermediary determinants (maternal age, parity, gestational distance, nutritional status, three of delays), and remote determinants (education, employment, and income) in Boyolali district.

Materials and methods: This was an observational analysis with case-control study with 21 cases and 42 controls with simple random sampling technique. Data analysis was done with univariate, bivariate with chi-square test, and multivariate with multiple logistic regression.

Results: Results showed a significant association between pregnancy complications $(p<0.001)$, maternal complications $(p<0.001)$, puerperal complications $(p<0.001)$, maternal age $(p=0.011)$, and gestational range $(p=0.035)$. There was no significant correlation between parity $(p=0858)$, nutritional status $(p=0.593)$, delay in decision-making $(p=0.848)$, and delay of place of reference $(p=0.530)$ to maternal deaths. There was no significant correlation between parity $(p=0.858)$, maternal education ( $p=0.363)$, maternal employment $(p=0.814)$, and family income ( $p=0.373$ ) to maternal deaths. The probability of a maternal death by having the above-mentioned risk factor is $85.5 \%$.

Conclusion: Pregnancy complication, labor complication, and parturition complication are related to an increase of maternal deaths, while maternal age and range of pregnancy are only slightly related to maternal deaths.

Clinical significance: We hope that this study may improve awareness and service of health practitioners toward pregnant mothers so that we can reduce the number of maternal deaths in Indonesia.

Keywords: Boyolali district, Determinant factors, Maternal death. How to cite this article: Respati SH, Taufiq AC, Sulistyowati S. Determinant Factors affecting Maternal Death in Boyolali District. J South Asian Feder Obst Gynae 2018;10(2):149-153.

Source of support: Nil

Conflict of interest: None

Date of received: 15 March 2018

Date of acceptance: 20 April 2018

Date of publication: July 2018

\footnotetext{
${ }^{1}$ Lecturer, ${ }^{2}$ Senior Resident, ${ }^{3} \mathrm{Head}$ of Lecturer

${ }^{1-3}$ Department of Obstetrics and Gynecology, Faculty of Medicine Sebelas Maret University, Surakarta, Central Java, Indonesia

Correspondind Author: Sri Sulistyowati, Department of Obstetrics and Gynecology, Faculty of Medicine, Sebelas Maret University, Surakarta, Surakarta, Central Java, Indonesia, e-mail: elis_spog@yahoo.co.id
}

\section{INTRODUCTION}

Maternal death rate is one of many indicators of nation's health, especially when related to mother and child's health, including women in pregnancy, labor, and parturition. ${ }^{1}$ Everyday in the world, around 830 women die due to complications during pregnancy or labor. In 2015, around 303,000 women died during pregnancy and after labor. ${ }^{2}$ Globally, maternal death rate decreases only 2.3\% per year from 1990 since 2015, except for several countries whose rate is above $5.5 \%$ between 2000 and 2010. Almost 99\% maternal deaths happen in developing countries, with more than half happening in Sub-Saharan Africa and almost a third occurs in South Asia. ${ }^{3}$ Indonesia ranks fourth in the list of highest maternal death rate in the Association of Southeast Asian Nation countries. Despite having a decrease in maternal death rate from 442 per 100,000 live births in 1990 to 126 per 100,000 live births in 2015, Indonesia still has not reached the target of Sustainable Development Goals of 102 per 100,000 live births by 2030. ${ }^{4}$ Data from the Health Department of Central Java show that in 2014, there were 711 cases of maternal death or 126.55 per 100,000 live births, while in 2015, this number decreased significantly to 619 cases or 111.16 per 100,000 live births. Boyolali district, as part of Central Java, has quite a high number of maternal deaths, with 14 people died in 2014 and 21 died in 2015. This indicates that the maternal death rate in Boyolali has increased significantly compared with previous year. ${ }^{5}$

Maternal deaths are usually related to low socioeconomic status and low health services facility, such as low prenatal and obstetrics services. Mothers usually do not have access to qualified health centers, especially in emergency settings, due to latency in knowing the danger signs and decision-making, late in reaching health facility, and delay in receiving services at health facilities. Maternal deaths are also related to the mother's own condition, and four "too" which are too old during pregnancy (more than 35 years), too many offspring (more than 4 ), parity range less than 2 years and too young during pregnancy (less than 20 years). ${ }^{5}$ There are three factors that affect maternal death. The closest factor, being a proximate determinant, is the pregnancy itself and complications that occur during pregnancy, labor, or parturition. Intermediate determinants include care services, reproductive health behavior, and women's health and nutrition status. Third 
factor is the contextual determinant, which is the furthest distance from maternal health outcomes, but still have influence on the outcomes. This determinant includes implementation of policies, infrastructures, especially in rural areas, and women's socioeconomic status. ${ }^{6}$ This study aims to identify the determinants that may have affected maternal deaths in Boyolali district, since there is an increase in maternal death from 2014 to 2015.

\section{MATERIALS AND METHODS}

This is an analytical observational study, with case-control design. The study was done in Boyolali district, and data of maternal deaths from the period 2015 to 2016 were taken from the Health Department of Boyolali district, while the control data were taken from local health centers in Boyolali district. There were 63 samples, consisting of 21 cases and 42 controls, in which the controls were chosen by simple random sampling. We wanted to identify any pregnancy, labor, and parturition complications, the mother's age, range of each pregnancy, parity, delay in decision-making, delay of reference due to transportation problem, delay in care by health facility, the mother's nutritional status during pregnancy, mother's education and occupation, and family income. These were asked using a questionnaire that was validated with secondary data taken from medical records. All respondents were asked to fill an inform consent, ensuring anonymity and confidentiality. Data analysis was done gradually, first by univariate analysis to describe maternal deaths based on risk factors between case and control groups. Then data were analyzed using bivariate analysis, to see the effect of delay in decision-making, primary care services, and secondary care services against maternal death, using chisquare, and to find out the odds ratio (OR). Multivariate analysis using logistic regression was done to fine the most fit and parsimony model that can describe the effect of above variables toward maternal deaths. Variables are considered significant when $p<0.05$. This study was approved by Dr. Moewardi General Hospital Health Research Ethics Committee (552/VI/HREC/2017) and all study participants signed an informed consent form before answering the questionnaire.

\section{RESULTS}

There were 21 cases of maternal deaths spread across 16 primary care centers in Boyolali district in 2015. There is 1 center with 3 maternal deaths, 3 centers with 2 maternal deaths, and 12 centers with 1 maternal death each. Control samples were taken from primary care centers that have maternal deaths, making a total of 63 samples.

Based on data from the health department of Boyolali district and from interviews with the case respondents, we found that the most common cause of maternal deaths is due to severe preeclampsia (75\%), followed by diseases that worsened the mother's conditions, such as infections during pregnancy, heart disease, tuberculosis, meningitis, and breast cancer $5 \%$ each respectively (Table 1). Most maternal deaths occur during parturition (52\%), then during labor and pregnancy at $24 \%$ each respectively.

Upon analysis of factors related to obstetric complications, pregnancy complication occurs in 18 (85.7\%) of cases, with OR of 25.50 and $p<0.001$, which is a significant factor for maternal death. Labor complications occur in $14(66.7 \%)$ cases and 10 times more likely to experience maternal deaths compared with control [OR = 10.00; 95\% confidence interval (CI): 2.96-33.78] and parturition complication in 11 (52.4\%) cases respectively (OR = 2.1; 95\% CI: 1.34-3.29) (Table 2). Mothers of the age 20 to 34

Table 1: Cause of maternal deaths in Boyolali district

\begin{tabular}{lll}
\hline Cause of maternal death & Amount & Percent \\
\hline $\begin{array}{l}\text { Death due to obstetric cause } \\
\text { Severe preeclampsia }\end{array}$ & 16 & 75 \\
$\begin{array}{l}\text { Infections during pregnancy } \\
\text { Death due to indirect obstetric cause }\end{array}$ & 1 & 5 \\
(during labor) & & \\
Heart disease & 1 & 5 \\
Tuberculosis & 1 & 5 \\
Meningitis & 1 & 5 \\
Breast cancer & 1 & 5 \\
\hline Total & 21 & 100 \\
\hline
\end{tabular}

Table 2: Factors related to obstetrics complications in Boyolali district

\begin{tabular}{|c|c|c|c|c|c|c|c|}
\hline & \multicolumn{2}{|c|}{ Case $(n=21)$} & \multicolumn{2}{|c|}{ Control $(n=42)$} & \multirow[b]{2}{*}{ OR } & \multirow[b]{2}{*}{$95 \% \mathrm{Cl}$} & \multirow[b]{2}{*}{$p$-value } \\
\hline & $n$ & Percent & $n$ & Percent & & & \\
\hline \multicolumn{8}{|c|}{ Pregnancy complication } \\
\hline Present & 18 & 85.7 & 8 & 19 & 25.50 & $6.0-108$ & $<0.001^{\mathrm{a}}$ \\
\hline Not present & 3 & 14.3 & 34 & 81 & & & \\
\hline \multicolumn{8}{|c|}{ Labor complication } \\
\hline Present & 14 & 66.7 & 7 & 16.7 & 10.00 & $2.96-33.78$ & $<0.001^{\mathrm{a}}$ \\
\hline Not present & 7 & 33.3 & 35 & 83.3 & & & \\
\hline \multicolumn{8}{|c|}{ Parturition complication } \\
\hline Present & 11 & 52.4 & - & - & 2.10 & $1.34-3.29$ & $<0.001^{\mathrm{a}}$ \\
\hline Not present & 10 & 47.6 & 42 & 100 & & & \\
\hline
\end{tabular}


Table 3: Reproductive factors in Boyolali district

\begin{tabular}{|c|c|c|c|c|c|c|c|}
\hline & \multicolumn{2}{|c|}{ Case $(n=21)$} & \multicolumn{2}{|c|}{ Control $(n=42)$} & \multirow[b]{2}{*}{ OR } & \multirow[b]{2}{*}{$95 \% \mathrm{Cl}$} & \multirow[b]{2}{*}{$p$-value } \\
\hline & $n$ & Percent & $n$ & Percent & & & \\
\hline \multicolumn{8}{|l|}{ Maternal age } \\
\hline$<20$ years or $>34$ years & 4 & 19 & 22 & 52.4 & 0.21 & $0.06-0.74$ & $0.01^{a}$ \\
\hline 20-34 years & 17 & 81 & 20 & 47.6 & & & \\
\hline \multicolumn{8}{|l|}{ Parity } \\
\hline$\leq 1$ time & 11 & 52.4 & 23 & 54.8 & 0.91 & $0.32-2.60$ & 0.858 \\
\hline$>1$ times & 10 & 47.6 & 19 & 45.2 & & & \\
\hline \multicolumn{8}{|c|}{ Duration between pregnancy } \\
\hline$<2$ years & 3 & 14.3 & 17 & 40.5 & 0.24 & $0.06-0.96$ & $0.035^{\mathrm{a}}$ \\
\hline$\geq 2$ years & 18 & 85.7 & 25 & 59.5 & & & \\
\hline \multicolumn{8}{|l|}{ Nutritional status } \\
\hline $\mathrm{BMI}<18.5 / \mathrm{BMI}>25.0$ & 11 & 52.4 & 19 & 45.2 & 1.13 & $0.47-3.81$ & 0.593 \\
\hline BMI 18.5-25.0 & 10 & 47.6 & 23 & 54.8 & & & \\
\hline
\end{tabular}

aSignificant; $p<0.05$

Table 4: Socioeconomic factor related to maternal death in Boyolali district

\begin{tabular}{|c|c|c|c|c|c|c|c|}
\hline & \multicolumn{2}{|c|}{ Case $(n=21)$} & \multicolumn{2}{|c|}{ Control $(n=42)$} & \multirow[b]{2}{*}{ OR } & \multirow[b]{2}{*}{$95 \% \mathrm{Cl}$} & \multirow[b]{2}{*}{$p$-value } \\
\hline & $n$ & Percent & $n$ & Percent & & & \\
\hline \multicolumn{8}{|l|}{ Education } \\
\hline Uneducated-high school & 18 & 85.7 & 39 & 92.9 & 0.46 & $0.08-2.51$ & 0.363 \\
\hline University & 3 & 14.3 & 3 & 7.1 & & & \\
\hline \multicolumn{8}{|l|}{ Occupation } \\
\hline Working & 4 & 19 & 7 & 16.7 & 1.17 & $0.30-4.58$ & 0.814 \\
\hline Not working & 17 & 81 & 35 & 83.3 & & & \\
\hline \multicolumn{8}{|l|}{ Income } \\
\hline Salary < average & 12 & 57.1 & 19 & 45.2 & 1.61 & $0.56-4.64$ & 0.373 \\
\hline Salary > average & 9 & 42.9 & 23 & 54.8 & & & \\
\hline
\end{tabular}

aSignificant; $p<0.05$

years $(81 \%)$ are considered at risk for maternal deaths; however, bivariate analysis shows that the chance of mothers at the age of 20 to 34 years having maternal death is only 0.21 , even though statistically significant (p 0.011). Parity also did not have any effect on maternal deaths (OR 0.91; $\mathrm{p}>0.05$ ) (Table 3). Delay in receiving service at health centers, which is more than 30 minutes is 1,105 times more likely to experience maternal death (OR: 1,105; 95\% CI: 0.96-1.27) and statistically, there is a significant effect between delay in receiving service with maternal death $(\mathrm{p}=0.042<0.05)$.

The proportion of socioeconomic status between case group and control group is almost the same, and bivariate analysis shows that education was not a risk factor for maternal death (OR 0.46; 95\% CI: 0.085-2.514), and statistically, there is no correlation between education and maternal death $(p=0.363>0.05)$. Bivariate analysis of mother's occupation shows that having an occupation is 1,176 more risky to experience maternal death (OR 1,176; $95 \%$ CI $0.30-4.58)$, although there was statistically no significant correlation between occupation and maternal death $(p=0.814>0.05)$. Having an income lower than the nationally appointed income is not statistically associated with maternal death, $(p=0.373>0.05)$; however it does
Table 5: Double regression logistic on independent variables

\begin{tabular}{|c|c|c|c|c|c|}
\hline Variables & $B$ & OR & $\mathrm{Cl} 95 \%$ & $p$-value & $R^{2}$ \\
\hline $\begin{array}{l}\text { Pregnancy } \\
\text { complication }\end{array}$ & 3.41 & 30.53 & $1.92-483.38$ & $0.015^{\mathrm{a}}$ & 0.855 \\
\hline Labor complication & 2.26 & 9.66 & $0.53-174.18$ & 0.124 & \\
\hline $\begin{array}{l}\text { Parturition } \\
\text { complication }\end{array}$ & 38.86 & 7.59 & - & 0.997 & \\
\hline Maternal age & -21.15 & 0 & - & 0.997 & \\
\hline $\begin{array}{l}\text { Duration between } \\
\text { pregnancy }\end{array}$ & -2.97 & 0.05 & $0.00-1.06$ & 0.055 & \\
\hline $\begin{array}{l}\text { Delay in receiving } \\
\text { services }\end{array}$ & 20.45 & 7.62 & - & 0.999 & \\
\hline
\end{tabular}

a Significant; $p<0.05$

increase the risk around 1,614 times more likely to cause maternal death (Table 4).

Multivariate analysis using regression logistic on all independent variables shows that there is only one independent variable that is statistically significant, which is pregnancy complication. Having pregnancy complication 30,530 times more likely results in maternal death $(\mathrm{OR}=$ 30,530, p = 0.015; CI 95\% = 1.928-483.381) (Table 5).

\section{DISCUSSION}

This study shows that having a pregnancy complication increases the risk of maternal death by 25.5 times. This 
is in accordance with the study of Handriani and Melaniani, ${ }^{7}$ Muthoharoh et $\mathrm{al}^{8}{ }^{8}$ and $A$ eni ${ }^{9}$ who stated that pregnancy complication increases the risk of maternal death by 147 times, 4.2 times, and 12 times respectively. The most common pregnancy complication in this study is preeclampsia. If not treated, preeclampsia may cause the mother to lose consciousness that results from heart failure, kidney failure, or brain hemorrhage leading to maternal death. ${ }^{10}$

Bivariate analysis of this study shows that mothers with labor complications are 10 times at risk to experience maternal death. This is in accordance with the study done by Muthoharoh et $\mathrm{al}^{8}$ and Aeni, ${ }^{9}$ which shows that having labor complication increases the risk of maternal death by 9.94 times and 4.2 times respectively. CavasozRehg et $\mathrm{al}^{11}$ stated that a mother's young age is related to parturition infection. Age less than 19 years is related to an increased risk of mild preeclampsia (60\% increased risk in 15-19 years). Meanwhile, older age (35-39 years) is related to an increase in hypertension by $30 \%$ and almost $80 \%$ for mother whose age is 40 years. However, this study did not find any correlation between maternal age and maternal death.

In this study, labor complication, especially postpartum hemorrhage, contributes to $25 \%$ of maternal death. Prolonged labor, which lasts for more than 18 hours, can endanger a mother's life, because there is an increased risk in postpartum hemorrhage, especially if the long labor is caused by head-pelvis disproportion, which leads to an increased risk of uterine rupture, hence resulting in maternal and infant's death. ${ }^{12}$

Infection is also a part of labor complication in this study. Long labor may cause an infection of birth canal, resulting in sepsis. Pregnant and peripartum women are intrinsically vulnerable due to a different maternal immune response that was previously arranged to protect the fetus, resulting in a decrease in immune mediated T-cells, which is important in immunity toward pathogens. ${ }^{13}$

This study did not find any correlation between parity and maternal death, which is similar to a study done by Muthoharoh et al. ${ }^{8}$ However, Kozuki et al ${ }^{14}$ mentioned in his study that parity and maternal age may increase prematurity and death. This study also did not find any correlation between range of pregnancies and maternal death. This is different from the statement of the National Health Department that says that the range of pregnancies less than 2 years can increase the risk of maternal death, because it is a risk factor for postpartum hemorrhage. The suggested range of pregnancy is at least 2 years, to ensure that a woman's body recovers from the extra energy needed during pregnancy and lactation. ${ }^{15}$

Nutritional status in this study has no effect on maternal death, similar to a study done by Muthoharoh et al. ${ }^{8}$
A pregnant woman generally needs folic acid, energy, proteins, iron, calcium, and vitamin D supplementations, especially in groups with high risk of sexually transmitted diseases and in countries with long winter seasons. ${ }^{16}$ Wrong dietary intake may cause nutritional imbalance, such as anemia and low weight gain in the pregnant mothers and impaired fetal growth. ${ }^{17}$

Delay in decision-making may be caused by several factors, such as tradition or belief in decision-making in families, inability to pay for the costs, delay in referring because family does not understand the danger signs of labor, delay of medical personnel in doing prevention, or identifying complication as early as possible, and medical personnel unable to advocate patient and the family regarding the importance of referring to save the mother's and child's lives. ${ }^{18}$ Statistical analysis in this study did not show any correlation between delay in decision-making, nor in reaching referral place with maternal death. However, there is correlation between delay in receiving health care and maternal death, with an increased risk of 1,105 times more likely to cause maternal death. Largely, this delay in receiving health care is caused by ineffective hospital administration system, unavailability of skilled health personnel, unavailable or unqualified facilities and infrastructures, patient arriving in hospital in "unsalvageable" condition, and not enough information in society regarding the facilities' capabilities in handling maternal and neonatal emergencies. $^{18}$

Education is not associated with maternal death in this study, which corresponds to studies done by Muthoharoh et $\mathrm{al}^{8}$ and Aeni' ${ }^{9}$; however, this is in contrast to a study by Bauserman et al, ${ }^{19}$ which states that uneducated person and a person with primary education has 3.2 and 3.4 times respectively more risk to experience maternal death. Education may indirectly relate to an increase in social status and mother's position in society, as well as an improvement in decisionmaking. Meanwhile, mothers with low education may have less understanding regarding the emergencies in pregnancy and labor.

\section{CONCLUSION}

This study concludes that pregnancy complication, labor complication, and parturition complication are related to an increase of maternal deaths, while maternal age and range of pregnancy is only slightly related to maternal deaths. Due to the complexity of factors affecting maternal death, some variables chosen in this study may not fully illustrate the problems. With this study, we hope that Indonesia's health department can improve antenatal care services and education toward expectant mothers so as to minimize maternal deaths. 


\section{CLINICAL SIGNIFICANCE}

To create awareness in health professionals regarding obstetrics, labor, and parturition complications that may occur in pregnant women, so as to reduce the number of maternal deaths. We hope that this study can be used to improve health services for pregnant women, especially those living in rural and remote areas, also increasing awareness of early detection of any complication that may occur during antenatal care, during labor, or during parturition.

\section{ACKNOWLEDGMENTS}

Authors would like to thank the Health Department of Boyolali District for their help and permission in doing this research. This research has been approved by Dr Moewardi General Hospital's Ethics Committee.

\section{REFERENCES}

1. Kemenkes, RI. Profil Kesehatan Indonesia tahun 2014. Jakarta: Kementerian Kesehatan RI, 2015.

2. Alkema L, Chou D, Hogan D, Zhang S, Moller A-B, Gemmill A, Fat DM, Boerma T, Temmerman M, Mathers C, et al. Global, regional, and national levels and trends in maternal mortality between 1990 and 2015, with scenario-based projections to 2030: a systematic analysis by the UN Maternal Mortality Estimation Inter-Agency Group. Lancet 2016 Jan;387(10017): 462-474.

3. WHO. Maternal mortality. Geneva: WHO; 2016. [cited 2017 Feb 21]. Available from: http:/ / www.who.int/mediacentre/ factsheets/fs348/en/.

4. WHO. Trends in maternal mortality: 1990 to 2015, Estimates by WHO, UNICEF, UNFPA, World Bank Group and the United Nations Population Division. Geneva: WHO; 2015. [cited 2017 Feb 21]. Available from: http://www.who.int/reproductivehealth/publications/monitoring/maternal-mortality2015/en/.

5. Jateng Gayeng. Profil Kesehatan Provinsi Jawa Tengah. Semarang: Dinas Kesehatan Propinsi Jawa Tengah; 2015.

6. Epuu, KG. Determinants of maternal morbidity and mortality, Turkana District, Kenya. Amsterdam: Royal tropical institute (KIT); 2010.
7. Handriani I, Melaniani S. Pengaruh Proses Rujukan Dan Komplikasi Terhadap Kematian Ibu. Jurnal Berkala Epidemiologi 2015 Sep;3(3):400-411.

8. Muthoharoh NA, Purnomo I, NurLatif V. Faktor-Faktor Yang Berhubungan Dengan Kematian Maternal Di Kabupaten Batang. Jurnal Pena Medika 2016 Jun;6(1):1-18.

9. Aeni N. Faktor Risiko Kematian Ibu. Jurnal Kesehatan Masyarakat Nasional 2013 May;7(10):453-459.

10. Shennan AH, Green M, Chappell LC. Maternal deaths in the UK: pre-eclampsia deaths are avoidable. Lancet 2017 Feb;389(10069):582-584.

11. Cavazos-Rehg PA, Krauss MJ, Spitznagel EL, Bommarito K, Madden T, Olsen MA, Subramaniam H, Peipert JF, Bierut LJ. Maternal age and risk of labor and delivery complications. Matern Child Health J 2015 Jun;19(6):1202-1211.

12. Smith, JR. Postpartum hemorrhage. Medscape; 2016. [cited 2017 Feb 20]. Available from: http://emedicine.medscape. com/article/275038-overview.

13. Acosta CD, Knight M. Sepsis and maternal mortality. Curr Opin Obstet Gynecol 2013 Apr;25(2):109-116.

14. Kozuki N, Lee AC, Silveira MF, Sania A, Vogel JP, Adair L, Barros F, Caulfield LE, Christian P, Fawzi W, et al. The associations of parity and maternal age with small-forgestational-age, preterm, and neonatal and infant mortality: a meta-analysis. BMC Public Health 2013 Sep;13(Suppl 3):S2.

15. Depkes, RI. Undang-Undang Lindungi Hak Anak Untuk Dapatkan Pelayanan Kesehatan. Jakarta: Departemen Kesehatan RI; 2016. [cited 2017 Feb 18]. Available from: http:/ / www.depkes.go.id/article/print/16051800001/undangundang-lindungi-hak-anak-untuk-dapatkan-pelayanan-kesehatan.html.

16. Kusmiyati, Y.; dkk. Perawatan Ibu Hamil. Yogyakarta: Fitramaya; 2008.

17. Ojofeitimi EO, Ogunjuyigbe PO, Sanusi RA, Orji EO, Akinlo A, Liasu SA, Owolabi OO. Poor dietary intake of energy and retinol among pregnant women: implications for pregnancy outcome in Southwest Nigeria. Pak J Nutr 2008 Mar;7(3): 480-484.

18. Kemenkes, RI. Riset Kesehatan Dasar. Jakarta: Badan Penelitian dan Pengembangan Kesehatan Kementerian Kesehatan RI; 2013.

19. Bauserman M, Lokangaka A, Thorsten V, Tshefu A, Goudar SS, Esamai F, Garces A, Saleem S, Pasha O, Patel A, et al. Risk factors for maternal death and trends in maternal mortality in low- and middle-income countries: a prospective longitudinal cohort analysis. Reprod Health 2015 Jun;12(Suppl 2):S5. 